\title{
Federalisme as 'n proses: 'n evaluering van die federalistiese momente in die 1996-grondwet
}

\author{
Lourens M. du Plessis \\ Departement Publiekreg \\ Universiteit van Stellenbosch \\ STELLENBOSCH
}

\begin{abstract}
Federalism as a process: An evaluation of federalist moments in South Africa's final Constitution of 1996

In this article the federalist elements in South Africa's final Constitution of 1996 are assessed. It is shown that due to historical forces the fullest possible (or "ideal") form of federalism has hardly been attainable in South Africa. This did not, however, result in a total exclusion of everything federalist in the final Constitution. Federalist structures are relatively weakly defined but provision is made for procedures which could give wings to centrifugal forces delermining the relationship between central government and the newly-created geographical components of the state (i.e. the nine provinces). These centrifugal forces are subject to centripetal checks and balances which do not, however, totally exclude the attainment of a relatively clearly pronounced federal state. Much will depend on how procedures and conflict resolution mechanisms provided for in the Constitution will be used. The federalist characteristics of the new South African state were not finally decreed by those negotiating the contents and "direction" of decentralist elements in the final Constitution. It is thus difficult to define South Africa as either a federation or a union. It is probably best described as an essentially unitary state divided into geographical units which could, in the course of time, differentiate into more pronounced components of a federal state in the classical sense.
\end{abstract}

\section{Inleidende opmerkings}

Sedert 27 April 1994 het Suid-Afrika 'n treffende voorbeeld geword van hoe om 'n vreedsame oorgang te bewerkstellig wat alle aspekte van die samelewing ingrypend raak. Die "nuwe" Suid-Afrika kan kwalik egter as 'n model federale staat voorgehou word. Federale state oor die algemeen toon bepaalde kemkenmerke wat met "federalisme" in verband gebring word - daar is 'n grondpatroon wat "federasie" genoem word. Die verwerkliking van hierdie kenmerke is egter in 'n groot mate 'n onnavolgbare antwoord op eise van 'n unieke situasie in die geskiedenis 
Die hieropvolgende artikel is in twee opsigte begrens:

- Eerstens voel regs- en grondwetkenners van demokratiese gesindheid hulle intellektueel aangetrokke tot federalistiese idees. 'n Intellektueel bevredigende model van federalisme is egter, vir die huidige altans, slegs deels haalbaar in Suid-Afrika. 'n Mens moet jou dus daarvan weerhou om 'n bedeling wat tans nog nie heeltemal ontvanklik daarvoor is nie, verhewe federalistiese ideale te probeer voorhou. 'n Eerlike waardering van die situasie verg eerder 'n bewussyn van die historiese werklikhede wat die ideaal bevorder sowel as teëhou. Hierdie artikel wil so 'n waardering wees.

- Tweedens is federalistiese denke in Suid-Afrika grotendeels deur Duitse idees beïnvloed (C.A., 1996; Karpen, 1994; Kotzé, 1995a:1-2; Molt, 1995) en, in 'n mindere mate, deur Amerikaanse idees en ervaringe (Elazar, 1994b; Kotzé, 1995a:1-3 en Mattes, 1995). Sodanige verbintenisse word egter nie in hierdie artikel volledig ondersoek nie.

Dit sal betoog word dat die federalistiese kenmerke in die Grondwet van die Republiek van Suid-Afrika, 1996 ("die finale Grondwet") gesoek moet word in die prosedures waarvoor dit met betrekking tot die vertikale verdeling van staatsgesag voorsiening maak, eerder as in die strukture wat dit skep (ofskoon laasgenoemde nie irrelevant is nie). 'n Oordeelkundige gebruik van sulke prosedures kan mettertyd 'n tradisie vestig wat in meer uitgesproke federale strukture neerslag vind.

\section{Historiese skets: $\mathbf{1 8 5 0 - 1 9 9 4}$}

Suid-Afrika se federale geskiedenis begin teen ongeveer 1850 (Barnard, 1992; Kotzé, 1995b:55-58; Kriek, 1992a en 1992b). Al het die koloniale moondheid, Brittanje, die onafhanklikheid van die Zuid-Afrikaanse Republiek (Transvaal) en die Oranje-Vrystaat in 1852 en 1854 onderskeidelik erken, het sekere individuele politici aanhou probeer om die hegemonie van die moederland te bestendig deur die skepping van federale strukture wat die twee republieke moes insluit. Onder diesulkes tel sir George Grey, lord Camavon, Cecil John Rhodes en sir Alfred Milner (Barnard, 1992:119-129). Hulle pogings was egter ondeugdelik. Selfs vir sewe jaar na die einde van die Tweede Vryheidsoorlog in 1902, toe die twee Boererepublieke gekoloniseer en aan Britse heerskappy onderwerp is, was federale strewes in Suid-Afrika steeds nie besonder lewensvatbaar nie. Die wyd uiteenlopende belange van die deeleenhede wat 'n federasie sou moes konstitueer, het pogings tot die skep daarvan gefnuik (Barnard, 1992:130-132).

Teen 1909 het die gety egter gedraai. 'n Slegs blanke, geheel manlike Nasionale Konvensie van die vier kolonies het op die daarstel van 'n eenheidstaat ooreengekom en die het op 31 Mei 1910 as die Unie van Suid-Afrika tot stand 
gekom. Die Konvensie het uiteindelik op 'n unitêre staat besluit maar tog sekere toegewings aan federalistiese sentimente gemaak (Kriek, 1992d:143-147).

Die 1910-grondwet (Zuid-Afrika Wet, 9 Edw. VII c. 9) het die staatsmag primêr in die sentrale regering laat setel met die wetgewende en uitvoerende jurisdiksie van die vier provinsiale regerings in spesifieke aangeleenthede soos onderwys, gesondheid, paaie en plaaslike regering, duidelik afgegrens. Die provinsiale rade het wetgewende gesag gehad en hierdie gesag is so vroeg soos 1914 deur die Appèlhof (in Middelburg Municipality v. Gertzen, 1914 A.D. 544 op 550) as 'n oorspronklike wetgewende kompetensie bestempel, met ander woorde 'n volledige en omvattende gesag om provinsiale wette (of ordonnasies) te maak (Du Plessis, 1986:11). Hierdie gevolgtrekking is waarskynlik deur federalistiese sentimente geïnspireer en hoewel dit in 'n reeks daaropvolgende hofuitsprake bevestig is, het die de facto wetgewende gesag van die provinsies, selfs in die aangeleenthede wat aan hulle toegewys is, ondergeskik gebly aan die wetgewende gesag van die soewereine nasionale parlement. Die provinsies was ook vir hulle finansies hoofsaaklik van die sentrale regering afhanklik en het slegs beperkte magte gehad om belastings te hef.

Die unitêre model van vertikale gesagsverdeling is onder die grondwette van 1961 (Gronowet van die Republiek van Suid-Afrika 32 van 1961) en 1983 (Grondwet van die Republiek van Suid-Afrika 110 van 1983) onveranderd gelaat. Dit het egter verander met die inwerkingtrede van die oorgangsgrondwet (Grondwet van die Republiek van Suid-Afrika, Wet 200 van 1993).

Dit kom vreemd voor dat na bykans 60 jaar van teenstand teen federalisme in Suid-Afrika, die Nasionale Konvensie in 1909 op 'n heel robuuste unitêre model besluit het. Dit moet egter gesien word as 'n kernstrategie in die vestiging van 'n bolwerk van wit hegemonie teen die swart meerderheid se aansprake op politieke mag en gelyke regte (Kriek, 1992b:140-141; Kotzé, 1995b:56) - en dit was suksesvol vir bykans 84 jaar!

Die geskiedenis van die Suid-Afrikaanse unie tussen 1910 en 1994 is besaai met voorbeelde van inbreukmaking op die gesagsfere van die provinsies in 'n poging om wit hegemonie deur die institusionalisering van apartheid te verstewig (Du Plessis \& Erasmus, 1988; Du Plessis, 1986:9-12). Die 1961-grondwet het byvoorbeeld die parlement verplig om nie sonder raadpleging van die provinsies hulle grense te verander nie. Hierdie vereiste is egter verontagsaam toe die tuislande - waarvan sommige later "volle onafhanklikheid" verkry het - se grense deur parlementêre wetgewing vasgestel is (Du Plessis, 1986:10-11). So 'n eensydige verandering van grense was tegnies moontlik omdat die grondwet ondergeskik was aan die wetgewende oppergesag van die parlement. 
Met 'n bietjie historiese ironie kan 'n mens dalk redeneer dat, grondwetlik gesproke, die oordra van mag aan nie-onafhanklike, selfregerende gebiede vir swartes (bv. die destydse KwaZulu), wesenlik op 'n federalistiese devolusie van staatsgesag neergekom het. Wetgewende en uitvoerende magte in sulke gebiede was inderdaad enigsins meer uitgebreid as in die tradisionele provinsies (Du Plessis, 1986:12). Hulle skepping was egter bedoel om "volle onafhanklikheid" wat deur die apartheidsregime voorsien is, vooraf te gaan. In plaas daarvan om federalisme te bevorder, was die hoofdoel dus eerder die skep van strukture wat 'n eventuele balkanisering van Suid-Afrika op 'n "verdeel en heers"-grondslag makliker sou maak.

Die inwerkingtrede van die Wet op Provinsiale Regering 69 van 1986 verteenwoordig 'n laagtepunt in Suid-Afrika se federale geskiedenis. Die parlement het met hierdie wet die provinsiale wetgewers (oftewel provinsiale rade) afgeskaf en wetgewende mag oorgedra aan die administrateurs van die provinsies, as organe van die uitvoerende gesag. Dit het provinsiale wette ("proklamasies" soos hulle van toe af genoem is) van oorspronklike tot ondergeskikte wetgewing verlaag (Du Plessis \& Erasmus, 1988:765-768). Vir die apartheidsregering was so 'n stap noodsaaklik om 'n rasgebasec:-de, beweerd konsosialistiese stelsel van "eie sake" en "algemene sake" wat deur die 1983-grondwet in die lewe geroep is, te kon implementeer.

In die dekade voor die veelparty grondwetlike onderhandelings van 1993 het die sienings van Suid-Afrikaanse politieke partye oor territoriale differensiasie en die aard en omvang van die gesag wat aan konstituerende eenhede toegeken moet word, van partisie tot unitarisme gewissel (Asmal, 1994; Cilliers, 1992; De Lille, 1995; Forsyth, 1984; Kenyon-Hoare, 1995; Kriek, 1992e; Leon, 1995; Meyer, 1995; Mtimkilu, 1995; Mulder, 1995 en Ngubane, 1995). 'n Tipering van vyf basiese standpunte (van die een "uiterste" tot die ander) sal 'n kemagtige oorsig oor die verskillende partye se sienings vergemaklik (Kotzé, 1995b:57). Hierdie standpunte (hieronder van (i)-(v) genommer om die verdere bespreking makliker te maak) is die volgende:

(i) partisie - 'n verdeling van die staat in kleiner, onafhanklike geografiese eenhede;

(ii) konfederasie (kyk ook Kriek, 1992c) - 'n partisiemodel waarin die eenhede sekere eng omskrewe en 'n beperkte aantal funksies deel;

(iii) konsosiasie - die politieke en ekonomiese elite verteenwoordigend van verskillende bevolkingseenhede word in die besluitnemingsproses betrek ten koste van massademokrasie; 
(iv) federasie - 'n devolusie van gesag wat begrensde outonomie vir die deeleenhede in hulle eie sfere erken, maar nogtans ' $n$ uiteindelike nakoming van en/of trou aan 'n sentrale gesag verg, en

(v) unitarisme - die inisiëring en uitoefening van gesag op die sentrale regeringsvlak met ' $n$ groot mate van beheer oor die funksionering van die nie-sentrale deeleenhede (indien enige).

Solank as wat die Nasionale Party (NP) aan bewind was, het dit gesag namens die wit minderheid uitgeoefen in die veronderstelling dat die wit bevolkingsdeel 'n landwye eenheid was. So gesien, was die NP' 'n unitariese party wat ruimskoots van die unitêre bepalings in drie agtereenvolgende grondwette gebruik gemaak het om in ' $n$ toenemende mate op die gesag van die provinsies inbreuk te maak. In die ontwerp van opsies en modelle om politieke gesag na swartes uit te brei, het die NP egter met standpunt (i) begin (partisie), deur standpunte (ii) (konfederasie) en (iii) (konsosiasie) gevorder en ten tye van die 1993-onderhandelings min of meer in die nabyheid van standpunt (iv) (federasie) geëindig.

Die "groot apartheidsontwerp" van die sestiger- en sewentigerjare het afsonderlike geografiese eenhede vir swartes en wittes voorsien waarin elkeen hulle politieke regte, onaflanklik van die ander, sou kon uitoefen. Hierdie siening is gedurende die tagtigerjare getemper. Die 1983-grondwet was 'n beweerd konsosialistiese uitbreiding van die politieke mag van die elitistiese wit minderheid na diegene onder die kleurling- en Asiatiese bevolkingsminderhede wat bereid was om "saam te werk". Die swart meerderheid is uitgesluit, maar daar was sprake daarvan dat hulle in 'n konfederasie van optimaal onafhanklike en nogtans interafhanklike state met gesamentlike besluitnemingsmagte in sake van gemeenskaplike belang gehuisves sou word. Na hierdie "eenheid" is mettertyd selfs as 'n "losse federasie" verwys.

Namate die NP in die rigting van standpunt (iv) (federasie) verskuif het, het regse wit politieke partye op sodanige verslapping van die klassieke apartheidsmodel gereageer met 'n aandrang op sesessie wat "selfbeskikking vir blankes" in 'n "kleiner" Suid-Afrika moontlik sou maak. Hierdie partye het dus min of meer in die nabyheid van standpunte (i) (partisie) en (ii) (konfederasie) gebly.

Teen dié agtergrond wat pas geskets is, het die swart bevrydingsbewegings, veral die African National Congress (ANC), gaandeweg agterdogtig geraak oor enige regeringsvorm waarvan differensiasie en veral territoriale desentralisasie beduidende elemente sou wees. Federalisme het vir diesulkes apartheid gespel. Slegs 'n onverdeelde, verenigde Suid-Afrika kon werklik vry wees. Ware bevryding, so is geglo, het 'n beslissende en sigbare breuk geverg met die idee van "verdeel en heers" wat deur Britse kolonialisme in die Suid-Afrikaanse politieke denke gevestig geraak het. Die swart bevrydingsgesentreerde voorkeur 
Federalisme as 'n proses: ' $n$ evaluering van die 1996-grondwet

vir standpunt (v) (unitarisme) was dus, anders as die wit minderheid se voorkeur vir dieselfde standpunt, 'n inklusivistiese poging om 'n geloofwaardige grondslag vir die vestiging van massademokrasie te lê.

Met die aanbreek van die politieke onderhandelingsfase in Suid-Afrika het die ANC behoedsaam in die rigting van standpunt (iv) (federasie) begin verskuif. Hierdie verskuiwing was 'n toegewing aan ander partye wat tydens die onderhandelinge op sterk vorme van federalisme aangedring het. Die Pan Africanist Congress (PAC) het egter onverswak 'n unitariese standpunt bly handhaaf.

Van die sterkste ondersteuners van federalisme in Suid-Afrika het uit die geledere van die vroeëre tuislande na vore getree. KwaZulu, vesting van Mangosotho Buthelezi se Inkatha Vryheidsparty (IVP), het hierin leiding geneem. Tydens veelpartyonderhandelings het enkele van die voormalige tuislande, veral KwaZulu, 'n vorm van territoriaal sterk gedesentraliseerde regering bepleit en dit "federalisme" genoem. So 'n regering kon help om hulle politieke magsbasisse intakt te hou - en dit was vir hulle belangrik omdat 'n gerieflike ANCmeerderheid in die 1994-verkiesing in die voonuitsig was. Hierdie desentralistiese standpunt was egter nie onverdund "federalisties" nie maar het dikwels tussen federalisme en konfederalisme gependel

Die sterk uitgesproke desentralistiese sentimente van die klassiek-liberale Demokratiese Party (DP) het waarskynlik die naaste gekom aan wat, in die moderne "eerstewêreldse" demokratiese spraakgebruik, "ware federalisme" sou heet (Kotzé, 1995b:64). Hierdie klein minderheidsparty het 'n sigbare stempel op die resultate van die veelpartyonderhandelings afgedruk, soos ook gesien kan word in die neerslag wat die federalistiese diskoers in die finale Grondwet gevind het.

Federalistiese elemente in albei Suid-Afrika se oorgangs- en finale grondwette is nie produkte van 'n versigtig beplande strategie of van 'n meesterplan wat gesagsdevolusie op ' $n$ territoriale grondslag inspan as ' $n$ middel om magsmisbruik deur die sentrale regering te voorkom of wat doeltreffende regering probeer verseker nie. Dit weerspıeël eerder 'n politieke vergelyk tussen sentralistiese en desentralistiese onderhandelaars in Kemptonpark en later in die Grondwetlike Vergadering - 'n vergelyk wat mettertyd sekere van die positiewe vrugte van federalisme kan dra.

\section{Die oorgangsdinamiek}

Die 26 (later 20) partye wat aan die Veelpartyonderhandelingsproses in Kemptonpark gedurende die grootste gedeelte van 1993 meegedoen het, het ooreengekom op 'n oorgangsgrondwet wat in artikel 68(1) 'n Grondwetlike 
Vergadering in die lewe roep. Die Grondwetlike Vergadering moes op 'n finale grondwet ooreenkom wat voldoen aan die 34 Grondwetlike Beginsels wat in bylae 4 tot die oorgangsgrondwet vervat is. Ingevolge artikel 71(2) moes die Konstitusionele Hof sodanige nakoming van die Grondwetlike Beginsels sertifiseer. Die afloop van die grondwetskrywende proses is teen hierdie tyd oorbekend. In hierdie artikel word slegs enkele elemente daarvan wat op die ontwikkeling van federalisme betrekking het, benadruk (kyk ook Chaskalson et al., 1996; De Coning, 1994; De Ville, 1995; De Villiers, 1994; Kotzé, 1995b:58-78; Shubane, 1994; Watts, 1994b en Welsh, 1994).

In die lig van die lewendige debat oor federalisme vóór 1993 was dit te wagte dat verskeie Grondwetlike Beginsels op federale elemente in die finale grondwet betrekking sou hê. Grondwetlike Beginsels XVI-XXVII het almal op die een of ander wyse hiermee te doen. Grondwetlike Beginsel XVIII is kort voor die 1994verkiesing gewysig ten einde die IVP se deelname aan daardie verkiesing te verseker. So het Grondwetlike Beginsel XVIII.2 die lig gesien. Hierdie beginsel het onder meer bepaal dat die "bevoegdhede en werksaamhede" van die provinsies in die finale grondwet nie wesenlik minder mag wees as (of wesenlik minderwaardig aan) dié in die oorgangsgrondwet nie.

In die historiese sertifiseringsuitspraak van die Konstitusionele Hof (In re: Certification of the Constitution of the Republic of South Africa, 1996 (1996(10) B.C.L.R. 1253 (C.C.)), het Beginsel XVIII.2 ook ter sprake gekom. Die hof het bevind dat die teks van die finale Grondwet waarop die Grondwetlike Vergadering ooreengekom het, nie aan hierdie beginsel voldoen nie omdat in die finale Grondwet die magte en funksies van die provinsies wesenlik minder of minderwaardig was in vergelyking met dié in die oorgangsgrondwet. Die hof het, om tot hierdie slotsom te kom, 'n hele aantal bepalings van die finale Grondwet wat op die magte en funksies van die provinsies betrekking het, saamgelees, en bevind dat die kumulatiewe effek van hierdie bepalings die magte en funksies van die provinsies wesenlik verminder en minderwaardig maak (Certification of the Constitution supra, pars. 306-481).

Die Grondwetlike Vergadering het daarna die teks gewysig, en die gewysigde teks is deur die Konstitusionele Hof gesertifiseer (Certification of the Amended Text of the Constitution of the Republic of South Africa. In re: Certification of the Amended Text of the Constitution of the Republic of South Africa, 1996, 1997 (1) B.C.L.R. I (C.C.)). Die hof het tot die slotsom gekom dat ofskoon die magte en funksies van die provinsies onder die finale Grondwet minder is as in die oorgangsgrondwet en selfs ook minderwaardig, dit nogtans nie gesê kan word dat hierdie magte en funksies wesenlik minder of minderwaardig is nie (par. 145-204 en in besonder par. 204(e)). Die sertifisering van die teks het die weg gebaan vir die inwerkingtrede van die finale Grondwet op 4 Februarie 1997 (artikel 243(1)). 
Federalisme as 'n proses: 'n evaluering van die 1996-grondwet

Twee (botsende) sienings van federalisme is onderliggend aan die desentralistiese bepalings in die oorgangsgrondwet:

One view at Kempton Park, perhaps dominant, saw federalism as a matter of dividing up spheres of competence ... An alternative vision ... foresaw much negotiation between the various units of governments (sic!) and looked to political processes ... for working out competences and conflicts (Chaskalson et al., 1996:5-1).

Sienings oor presies hoe "federaal" die oorgangsgrondwet is, loop wyd uiteen (De Coning, 1994, De Ville, 1995; Elazar, 1994a; Kriek \& Sono, 1995 [hulle huldig regstreeks strydige sienings]; Leonardy, 1994; Shubane, 1994 en Watts, 1994a). Die stelsel van vertikale magsdevolusie in die oorgangsgrondwet kan miskien die beste beskryf word as 'n federale stelsel met unitêre kenmerke (Chaskalson et al., 1996:5-1) - in teenstelling met die stelsel vóór 1986 wat 'n wesenlik unitêre stelsel met federale kenmerke was (kyk par. 2 hierbo)

Die federalistiese bepalings in die finale Grondwet weerspieël ' $n$ verskuiwing in die rigting van die tweede siening in die aanhaling hierbo. Dit impliseer ' $n$ fokusverplasing vanaf federale sirukture na federale prosesse - soos verder aan in hierdie bespreking ook redeneer sal word. Gedurende die oorgangsfase tot dusver was daar aansienlike magte wat sowel vir as téén 'n uitgesproke desentralisasie van regeringsgesag gewerk het.

Een van die tasbaarste gevolge van die hoofstuk oor provinsiale regering (hoofstuk 9) in die oorgangsgrondwet was die vermeerdering van die aantal provinsies van vier tot nege (artikel 124). In hulle kort bestaan het hierdie provinsies daarin geslaag om hulleself te vestig as politieke magsfaktore waarmee deeglik rekening gehou moet word, en hulle geniet wydverspreide legitimiteit. Die provinsies word egter ongelukkig met wisselende grade van sukses regeer. Sommige provinsiale regerings het oor die algemeen ' $n$ verbasende vermoë getoon om binne hulle jurisdiksiegebiede onafhanklik (en in sommige gevalle selfs merkwaardig kreatief) op te tree. Al hierdie faktore is bevorderlik vir federalisme

Daar is egter ook kragte wat teen federalisme werk. Leidende politici op die nasionale vlak, veral in die ANC, ervaar oënskynlik die prominensie en mag van sommige provinsiale leiers as bedreigend vir hulle eie ambisie. Een manier om die vlerke van die "leidende ligte" in die provinsies te knip, sou wees om die magte van die provinsies in die grondwet in te kort.

'n Té konsekwent klassiek-federalistiese gesagsdevolusie kan ook pogings onder leiding van die sentrale regering om middele onder die provinsies te herverdeel, kortwiek. Daar is aanmerklike verskille in die welvaartsvlakke van die verskillende provinsies (kyk bv. Financial and Fiscal Commission, 1995 en 
1996). Vir die ANC is dit voorts betekenisvol dat dit in twee van die drie mees welvarende provinsies nie die regerende party is nie.

Ten spyte van duidelike, inhiberende faktore is federalisme in Suid-Afrika nie heeltemal in 'n getygolf van sentralisme verswelg nie. Dit kan waarskynlik toegeskryf word aan die onderhandelingsinsette van invloedryke politieke rolspelers met gevestigde belange in provinsiale magstrukture.

Die nege provinsies is in die finale Grondwet onveranderd gelaat (artikel 103). Die stelsel van provinsiale regering onder hierdie grondwet weerspieël sowel die middelpuntvliedende as die middelpuntsoekende kragte wat vorm daaraan help gee het. Sommige elemente daarvan aktiveer middelpuntvliedende en andere middelpuntsoekende kragte in verhouding tot die sentrale regering. Geeneen van die betrokke elemente doen egter slegs die een of die ander nie: middelpuntvliedende kragte word beperk deur middelpuntsoekende remme en teëwigte en omgekeerd. (Die begrippe "middelpuntvliedend" en "middelpuntsoekend" word hier nie as alternatiewe gebruik soos wat Kriek [1992b:19] dit oënskynlik doen nie.)

Vervolgens word die stelsel van magsdevolusie na die provinsies onder die finale Grondwet kortliks geskets met verwysing na die interaksie tussen middelpuntvliedende en middelpuntsoekende kragte.

\section{4. 'n Regering van samewerking (co-operative government)}

In hoofstuk 3 van die finale Grondwet (die hoofstuk wat onmiddellik na die Handves van Regte in hoofstuk 2 volg) word beslag gegee aan die konsep van 'n regering van samewerking. Die uitgangspunt is dat die regering van die Republiek "bestaan uit nasionale, provinsiale en plaaslike sfere van regering wat onderskeidend, onderling afhanklik en onderling verbonde is" (artikel 40(1)). Artikel $41(1)$ lê vervolgens sekere middelpuntsoekende beginsels van samewerkende regering (en intra-regeringsverhoudings) neer waaraan alle staatsorgane gebonde is (kyk ook artikel 40(2)). Hierdie beginsels sluit die volgende in:

- die bewaring van die vrede, die nasionale eenheid en die onverdeelbaarheid van die Republiek (artikel 41(1)(a)),

- die versekering van die welsyn van die mense van die Republiek (artikel $41(1)(b))$

- die voorsiening van doeltreffende, deursigtige, verantwoordingspligtige en samehangende regering vir die Republiek as 'n geheel (artikel 4l(1)(c));

- getrouheid aan die grondwet, die Republiek en sy mense (artikel 41(1)(d)); 
Federalisme as 'n proses: 'n evaluering van die 1996-grondwet

- eerbied vir die grondwetlike status, instellings, bevoegdhede en funksies van regering in ander sfere (of op ander vlakke) (artikel $41(1)(\mathrm{e})$ );

- die nie-toeëiening van bevoegdhede en funksies anders as dié wat deur die grondwet aan ' $n$ betrokke regeringsfeer opgedra is (artikel 41(1)(f));

- die uitoefening van bevoegdhede en die verrigting van funksies op 'n wyse wat nie inbreuk maak op die geografiese, funksionele of institutionele integriteit van ander regeringsfere nie (artikel $4 \mathrm{l}(\mathrm{l})(\mathrm{g}))$, en

- samewerking met mekaar in wedersydse vertroue en in goeie trou deur

- vriendskaplike betrekkinge te bevorder;

- mekaar te help en te ondersteun;

- mekaar in te lig en met mekaar oorleg te pleeg oor sake van gemeenskaplike belang;

- optrede en wetgewing met mekaar te koördineer;

- ooreengekome prosedures te eerbiedig, en

- gedingvoering teen mekaar te vermy (artikel 4l(1)(h)(i)-(vi))

Die gemelde beginsels kenteken 'n strewe om die integriteit en "geheelheid" van die Republiek te bewaar en is in werklikheid uitdrukking van die Suid-Afrikaanse weergawe van Bundestreue. Die saad van hierdie beginsel is in die Grondwetlike Vergadering gesaai deur 'n afvaardiging wat die Duitse Bondsrepubliek van 9-15 Januarie 1996 besoek het ten einde met federalisme in daardie land vertroud te raak (C.A., 1996).

Schneider en Kramer (1996:20) kenskets die invloed van die idee van samewerkende regering op federalistiese strukture in Suid-Afrika se finale Grondwet treffend soos volg:

Nicht Gewaltentrennung, Kompetenzverteilung, Machthemmung, Konkurrenz und Konflikt zeichnen es aus, sondern vertikale und horizontale Zusammenarbeit. Kompetenzverbindung, Machtteilhabe sowie wechselseitige Information, Abstimmung, Hilfe und Unterstützung.

\section{Provinsiale grondwette}

Die finale Grondwet - net soos artikels 160-162 van die oorgangsgrondwet erken die gesag van die provinsies om hulle eie grondwette aan te neem (artikels 104(1)(a) en 142), onderworpe aan sekere beperkings (artikel 143). Die bepalings van 'n provinsiale grondwet mag nie onbestaanbaar wees met die nasionale grondwet nie (artikel 143(1)), moet voldoen aan die basiese waardes van demokrasie en konstitusionalisme soos in artikel I van die nasionale grondwet uiteengesit asook met die beginsels van 'n regering van samewerking in 
Lourens M. du Plessis

hoofstuk 3 (artikel 143(2)(a)). 'n Provinsiale grondwet mag ook nie aan die provinsies magte en funksies opdra wat die nasionale grondwet nie aan hulle verleen nie (artikel 143(2)(b)(i) en (ii)). 'n Provinsiale grondwet kan egter voorsiening maak vir provinsiale wetgewende en uitvoerende strukture en prosedures wat verskil van dié waarvoor in die nasionale grondwet voorsiening gemaak word (artikel 143(1)(a)) asook vir die instelling, rol, gesag en status van 'n tradisionele monarg (artikel 143(1)(b)). Die Konstitusionele Hof moet sertifiseer dat ' $n$ provinsiale grondwet behoorlik aangeneem is en dat die teks voldoen aan die vereistes van artikel 143 (artikel 144).

Artikel 143 het 'n oorwegend middelpuntvliedende werking wat egter deur besliste middelpuntsoekende beperkings getemper word.

\section{Provinsiale wetgewende gesag}

Artikel 43 van die finale Grondwet verleen die wetgewende gesag in die Republiek aan drie soorte wetgewers op drie vlakke van regering: aan die parlement in die nasionale sfeer (artikel 43(a)), aan provinsiale wetgewers in die provinsiale sfeer (artikel 43(b)) en aan munisipale rade in die plaaslike sfeer (artikel 43(c)) van regering. Hierdie betekenisvolle bepaling het waarskynlik tot gevolg dat elke wetgewer in eie sfeer oorspronklike wetgewing aanneem en nie ondergeskikte wetgewing nie (kyk par. 2 hierbo). Dit behels met ander woorde ' $n$ herstel van die wetgewende status van die provinsies tot die vlak waar dit voor 1986 was en dit verleen aan munisipale rade 'n status wat hulle nog nooit vantevore gehad het nie (kyk ook par. 9 infra).

Met die koms van konstitusionalisme in Suid-Afrika het die onderskeid tussen oorspronklike en ondergeskikte wetgewing waarskynlik veel aan betekenis ingeboet. Onder die bestel van parlementêre oppergesag kon 'n geregshof nie 'n oorspronklike wet ongeldig verklaar op grond van inhoudsoorwegings nie, maar slegs indien daar 'n gebrek was in die prosedure waarvolgens dit aangeneem is. Ondergeskikte wetgewing, daarenteen, kon - ooreenkomstig die gemenereg (soos uitgespel in die Engelse gewysde, Kruse v. Johnson [1898] 2 Q.B.D. 91) - ook op inhoudelike gronde ongeldig verklaar word, dit wil sê indien dit onredelik, diskriminerend of terugwerkend was. Tans is alle wetgewing wat of formeel of inhoudelik met die oppermagtige grondwet in stryd is, ongeldig, derhalwe het die onderskeid tussen oorspronklike en ondergeskikte wetgewing vervaag. Die gemeenregtelike toetsingsgronde het egter nie verval nie en ondergeskikte wetgewing is in beginsel steeds aan oorspronklike wetgewing toetsbaar. Oorspronklike wetgewing behou dus 'n hoër status

'n Bepaalde vergestalting van regterlike selfbeheersing, soos verwoord deur waarnemende regter Kentridge in die Konstitusionele Hof se uitspraak in $S$. $v$. 
Federalisme as 'n proses: 'n evaluering van die 1996-grontwet

Mhlungu and others 1995(7) B.C.L.R. 793 (C.C.), kan in hierdie verband ter sake wees. Regter Kentridge sê die volgende:

I would lay it down as a general principle that where it is possible to decide any case, civil or criminal, without reaching a constitutional issue, that is the course which should be followed (kyk ook Zantsi v. Council of State, Ciskei and others 1995(10) B.C.L.R. 1424 (C.C.) par. 3; Gardener v. Whitaker 1996(6) B.C.L.R. 775 (C.C.) par. 14).

Hierdie dictum impliseer dat wanneer ondergeskikte wetgewing getoets word, 'n hof sover moontlik sal probeer om gemeenregtelike eerder as grondwetlike standaarde daar te stel ten einde 'n konstitusionalisering van geskilpunte uit te skakel. Dit is egter nouliks denkbaar dat waardes soos geregtigheid, redelikheid en gelykheid wat in die gemenereg en oorspronklike wetgewing beliggaam is, eerder as gelykluidende waardes in die soewereine grondwet gebruik sal word om ondergeskikte wetgewing te toets. Artikel $8(1)$ van die finale Grondwet onderwerp immers die promulgering van ondergeskikte wetgewing deur die uitvoerende gesag regstreeks aan die Handves van Regte waarin hierdie waardes verwoord word.

Ten spyte van etlike vernuwings op die gebied van provinsiale wetgewende magte in die finale Grondwet bly die hantering van teenstrydighede tussen nasionale en provinsiale wetgewing enigermate problematies. Die kernvraag is hoe om konflikte doeltreffend te beredder sonder om enersyds die provinsies se wetgewende magte heeltemal uit te hol en andersyds die sentrale gesag van die parlement as doeltreffende nasionale wetgewer te ondermyn.

Ingevolge artikel 126 van die oorgangsgrondwet (saamgelees met bylae 6) word sekere besondere aangeleenthede aan die wetgewende jurisdiksie van die provinsies toegewys. Die parlement kan egter ook oor hierdie aangeleenthede wette maak en artikel 126(3) maak gevolglik voorsiening vir sekere voorwaardes waarop nasionale wetgewing voorkeur sal geniet bo provinsiale wetgewing. Die vertolking van hierdie bepalings was, om die minste te sê, nie onomstrede nie (kyk bv. De Ville, 1995).

Bylae 5 tot die finale Grondwet bevat 'n lys van funksionele gebiede waaroor die provinsiale wetgewers uitsluitlike gesag het (kyk ook artikel 104(b)(ii)). Artikel 44(2) magtig nogtans die parlement om wetgewend in te gryp selfs op die bylae 5-terreine, indien 'n grondwetlik duidelik omskrewe omstandigheidseis dit sou verg

Bylae 4 bevat 'n lys van funksionele gebiede van konkurrente nasionale en provinsiale wetgewende gesag, met ander woorde terreine waarop sowel die parlement (artikel 44(1)(a)(ii)) as provinsiale wetgewers (artikel 104(1)(b)(i)) wette kan maak. Dit beteken dus dat nasionale en provinsiale wetgewing 
Lourens M. du Plessis

teenstrydig kan wees in welke geval artikel 146 (wat 'n mens nogal aan artikel 126(3) van die oorgangsgrondwet herinner) voorsiening maak vir die opheffing van die laasgenoemde. Botsings tussen provinsiale grondwette en nasionale wetgewing word op 'n soortgelyke manier gehanteer (artikel 147(1)(c)).

Die ratio vir baie van die opheffings wat artikel 146 magtig, is die wisselende vlakke van welvaart tussen die verskillende provinsies (kyk ook par. 3 hierbo). Die regerende ANC het bepaald sterk gestaan op 'n stelsel wat dit nie moontlik sou maak vir die provinsies - veral die twee meer welvarendes waarin dit nie die regerende party is nie - om nasionaalgerigte heropbou- en ontwikkelingspogings te fnuik nie, en was opsigtelik suksesvol in die bedinging van so 'n bestel Artikel 146 soos oorspronklik deur die Grondwetlike Vergadering aanvaar, het trouens vir meer ingrypende opheffingsmagte voorsiening gemaak as die uiteindelike (huidige) weergawe. Die Konstitusionele Hof het egter bevind dat die eerste weergawe in stryd was met Grondwetlike Beginsel XVIII.2 omdat, saamgelees met ander grondwetlike bepalings wat provinsiale magte beperk, dit tot gevolg gehad het dat die magte en funksies van die provinsies onder die finale grondwet wesenlik minder of minderwaardig sou wees in vergelyking met dié in die oorgangsgrondwet (Certification of the Constitution supra par. 480-481)

Ten einde teenstrydighede tussen nasionale en provinsiale wetgewing met betrekking tot moontlike opheffings te probeer beperk, vereis artikel 150 dat indien daar 'n redelike vertolking is waarvolgens ' $n$ parlementswet en 'n provinsiale wet versoenbaar is, daardie vertolking verkies moet word bo een wat 'n teenstrydigheid tot gevolg het. Die beginsels van 'n regering van samewerking kan ook aangewend word om konfliksituasies te "versag". Artikel 41(3) verplig staatsorgane om elke redelike poging aan te wend om geskille tussen hulle te besleg voordat hulle hul op 'n hof beroep. 'n Hof kan weier om 'n saak aan te hoor indien sulke pogings nie aangewend is nie (artikel 4l(4)). Indien 'n teenstrydigheid wat met so 'n dispuut in verband staan egter nie deur 'n hof uit die weg geruim kan word nie, het die parlementswet voorrang bo die provinsiale wet (artikel 148).

Wetgewende mag vir die provinsies op bepaalde terreine, stel middelpuntvliedende magte vry. In Suid-Afrika is die middelpuntsoekende remme en teëwigte op hierdie magte egter so kragtig dat hulle 'n latente bron van onstredenheid en konflik tussen die sentrale en die provinsiale regerings is. Op hierdie terrein sal die lewensvatbaarheid van die regering van samewerking - en die doeltreffendheid van grondwetlike konflikhanteringsmeganismes - waarskynlik dus aan die strafste toetsing onderwerp word.

Bemerkenswaardig is egter die feit dat artikel 146(5) uitdruklik bepaal dat indien die voorwaardes vir 'n opheffing nie nagekom is nie, 'n provinsiale wet voorrang 
Federalisme as 'n proses: 'n evaluering van die 1996-grondwet

bo 'n parlementswet geniet. Hierdie bepaling versterk die (beperkte) middelpuntvliedende werking van provinsiale wetgewende mag.

\section{Nasionale wetgewende konteks: die Nasionele Raad van Provinsies (NRP)}

Die Nasionale Raad van Provinsies (NRP) is 'n tweede kamer van die parlement (artikel 42(1)(b)) en dit verteenwoordig die provinsies op sentrale wetgewende vlak "ten einde te verseker dat provinsiale belange in die nasionale regeringsfeer in ag geneem word" (Artikel 42(4)). Dit bestaan uit nege tienpersoonafvaardigings, een afvaardiging uit elke provinsie, onder leiding van die onderskeie provinsiale premiers (artikel 60). 'n Wetsontwerp wat die provinsies of provinsiale belange raak (artikel 76(3)-(5)) moet na die NRP verwys word nadat die Nasionale Vergadering (as eerste kamer van die parlement) dit aangeneem het (artikel 76(1)). Die NRP kan die wetsontwerp dan aanneem, wysig of verwerp (artikel 76(1)(a)(i)-(iii)). 'n Wetsontwerp wat deur die NRP gewysig is, moet na die Nasionale Vergadering terugverwys word.

Indien die Nasionale Vergadering en die NRP nie oor 'n wetsontwerp kan saamstem nie, skryf artikel 76 'n versoeningsprosedure voor wat 'n Bemiddelingskomitee betrek. Dié komitee bestaan uit agtien lede, nege lede uit die Nasionale Vergadering en nege uit die NRP, met in die laasgenoemde groep, een verteenwoordiger uit elke provinsie (artikel 76(1)(d)-(k) en (2)(d)-(i) saamgelees met artikel 78). Uiteindelik, indien ooreenstemming nog nie bereik kan word nie, kan die Nasionale Vergadering steeds die wetsontwerp aanneem maar dan alleen met 'n tweederdemeerderheid.

Die NRP mag ook wetgewing op ' $n$ funksionele gebied in bylae 4 of wetgewing soos omskryf in artikel 76(3) voorberei, maar dit mag nie monetêre wetsontwerpe voorberei of inisieer nie (artikel 68(b)).

Die skepping van die NRP was bepaald bedoel om 'n middelpuntsoekende effek te hê. Dit het egter nie noodwendig 'n verswakking van provinsiale regering tot gevolg nie. Die provinsies se aansienlike medeseggenskap op nasionale vlak in aangeleenthede wat hulle raak (en veral in die wetgewende proses), sal hulle in die praktyk waarskynlik in verhouding tot die sentrale regering bemagtig omdat hulle deur die NRP tot die sentrale magsechelon toetree. Die NRP kan byvoorbeeld help om 'n nasionaal-wetgewende ingrype in of opheffing van provinsiale wetgewing hoogstens te fnuik of minstens te beperk. Wetgewing wat 'n ingrype of opheffing daarstel (kyk ook par. 6 hierbo), raak onvernydelik provinsiale belange en moet dus na die NRP verwys word. 


\section{Finansies}

Ingevolge die finale Grondwet is die provinsies grotendeels van die sentrale regering afhanklik vir die toewysing van finansiële middele om hulle sake te hanteer (hoofstuk 13). Die oordrag van fondse aan 'n provinsie kan egter slegs gestaak word in gevalle van wanaanwending of wanbestuur (artikel 216).

Provinsiale magte om belasting te hef is toereikend maar nie omvattend nie. Die heffing van sulke belastings mag byvoorbeeld nie nasionale ekonomiese belange wesenlik of onredelik benadeel nie en dit moet deur ' $n$ parlementswet gereguleer word. So 'n wet kan slegs aangeneem word nadat aanbevelings van die Finansiële en Fiskale Kommissie (waarop die provinsies ook verteenwoordig is) oorweeg is (artikel 228).

Indien die finansiële onaflanklikheid van deeleenhede die toets sou wees om te bepaal hoe uitgesproke federaal die Suid-Afrikaanse stelsel van vertikale magsverdeling is, sal die stelsel kwalik as "'n federasie" beskryf kon word.

\section{Plaaslike regering}

Die betreklik omvattende voorsiening wat in hoofstuk 7 van die finale Grondwet (net soos in hoofstuk 10 van die oorgangsgrondwet) vir die hoofaspekte van plaaslike regering gemaak word, is 'n nuwigheid in Suid-Afrika. Dit verhoog die status van plaaslike regering. Vroeër (in par. 6 hierbo) is ook geredeneer dat die manier waarop wetgewende magte aan munisipale rade toegesê word, hulle wetgewende status waarskynlik ook verhoog. Dit alles voorspel veel goeds vir die bestendiging en versterking van middelpuntvliedende magte in die nuwe bedeling.

\section{Federalisme en etniese konflik}

"Klassieke federalisme", dit wil sê vertikale gesagsverdeling op 'n geografiese grondslag, word nie in die finale Grondwet voorsien as middel om moontlike etniese konflikte te hanteer nie. Dít sou in elk geval, in die lig van Suid-Afrika se apartheidsgeskiedenis, vir die meerderheid van die bevolking onaanvaarbaar wees. Daarbenewens maak die geografiese verspreiding van etniese groepe dit haas onmoontlik om lewensvatbare "etniese provinsies" te skep.

Die finale Grondwet is egter nie etnies-onvriendelik nie - inteendeel. Eenheid in etniese verskeidenheid is ' $n$ uitgesproke grondwetlike waarde - soos uit die aanhef blyk. Die verskansing van 'n reg op vrye assosiasie (artikel 18) en die verbod op diskriminasie op grond van (onder meer) etniese herkoms, kultuur, taal en geboorte (artikel 9(3)) rugsteun hierdie waarde juridies; so ook die verskansing van taal- en kultuurregte in artikels 30 en 31 . Artikel 185 roep selfs 'n kommissie in die lewe wat moet omsien na die bevordering en beskerming van 
Federalisme as 'n proses: 'n evaluering van die 1996-grondwet

die belange van kulturele, godsdienstige en taalgemeenskappe en artikel 235 erken (al is dit, regseffektief gesproke, 'n bietjie tong in die kies) 'n reg op selfbeskikking vir gemeenskappe wat 'n kultuur-en taalerfenis deel.

Kulturele konflik spruit nie noodwendig voort slegs uit etniese verskille nie. Spanninge tussen die "wêrelde" van modernistiese en tradisionalistiese leefwyses onder 'n wesenlik modernistiese grondwetlike bestel kan dit ook veroorsaak (Du Plessis \& Corder, 1994:36-37). Hoofstuk 12 van die finale Grondwet erken die instelling, rol en status van tradisionele leierskap en die daarmee gepaardgaande gewoontereg en artikel 15(3) veroorloof 'n (toekomstige) wetlike erkenning van tradisionele huwelike en persoonlike reg - alles in 'n poging om moontlike kulturele konflikte te beredder. Sommige tradisionaliste kan die voormelde twee pogings dalk as ondeugdelik afmaak omdat dit in albei gevalle duidelik gemaak word dat grondwetlike waardes steeds die botoon voer.

\section{Waarderende slotsom}

As ' $n$ federalistiese fynproewer iemand sou wees met 'n onversadigbare aptyt vir soveel moontlik desentralisasie en devolusie van staatsgesag, sal die vertikale magsverdeling in die finale Suid-Afrikaanse Grondwet waarskynlik nie op sy of haar spyskaart van federalistiese fynproewersgeregte verskyn nie. So 'n smaakvoorkeur is egter nie al wat "federalisties" is nie en loop trouens gevaar om die middelpuntsoekende bestanddele in enige federale bedeling té gering te skat. Die Suid-Afrikaanse voorbeeld wys dat sulke bestanddele ook noodsaaklik kan wees om die deeleenhede in ' $n$ federasie in verhouding tot die sentrale owerheid te bemagtig.

Die simmetrie en/of a-simmetrie van 'n federale bedeling word dikwels as riglyn gebruik om dit akkuraat te probeer tipeer (Boase, 1994). Watts (1994c:12) wys egter daarop dat:

[w] hile differences in population and wealth of constituent units within federal systems have inevitably introduced some asymmetry in the relative political power and influence of different units ..., in most federal systems the formal constitutional powers allocated to the constituent units have been symmetrical.

Hiervan is Suid-Afrika ' $n$ treffende voorbeeld. Dit is juis as gevolg van 'n aanmerklike a-simmetrie in die verdeling van middele en welvaart tussen die provinsies dat partye wat sterk op 'n omvattende uitwis van ongelykhede oor die hele spektrum staan, aangedring het op federale simmetrie in die Grondwet. Hierdie stelsel is egter nie onveranderlik nie. In baie gevalle kan op prosesse (eerder as strukture) gesteun word om tussen middelpuntvliedende en middelpuntsoekende magte te beredder. 
Lourens M. du Plessis

Die vertikaal desentralistiese bestel in Suid-Afrika se finale Grondwet kan kwalik as "federaal met unitêre kenmerke" beskryf word. Dié siening is té "staties". Meer "dinamies" bekyk, is Suid-Afrika 'n wesenlik unitêre staat, onderverdeel in geografiese eenhede wat kan ontwikkel tot vollediger gedesentraliseerde onderdele van 'n volbloed federale staat, namate nasionale doelwitte wat die ewewig tussen meer en minder welvarende deeleenhede moet herstel, verwesenlik kan word.

Federalisme en regionalisme as vorme van vertikale magsverdeling is kenmerkend van konstitusionalisme soos dit hedendaags verstaan word (Olivier, 1994:66-70). In hoe ' $n$ mate hierdie dimensie van konstitusionalisme in die "nuwe Suid-Afrika" verwerklik (gaan) word, is nie duidelik bloot uit die federalistiese strukture wat die finale Grondwet skep nie. Wat tans, optimaal gesien, federalisme-in-wording is, kan tot federalisme-in-verwording degenereer indien federalistiese prosesse ingevolge die finale Grondwet hulle nie in die vertikaal-magsdesentralistiese meganismes binne die grondwetlike bestel sou vestig nie. Tyd alleen sal leer of ook hierdie belangrike dimensie van konstitusionalisme in Suid-Afrika tot volle verwesenliking kan kom.

\section{Bibliografie}

ASMAL, Kader. 1994 Federalism and the proposals of the National and Democratic Parties. (In Licht, Robert A. \& De Villiers, Bertus eds. South Africa's crisis of constitutional democracy Can the US Constitution help? Washington DC : A.E.I. Press. p. 47-61.)

BARNARD, L.S. 1992. The attempts of the British government to establish a federation in South Africa during the second half of the nineteenth century. (In Kriek, D.J. ed. Federalism: The solution? Pretoria : RGN-uitgewers. p. 117-134.)

BOASE, Joan Price. 1994 Faces of asymmetry: German and Canadian Federalism. (In De Villiers, Bertus ed. Evaluating federal systems. Kaapstad : Juta, Dordrecht/Boston/

C.A Londen : Nijhoff. p. 90-110.)

Kyk

CONSTITUTIONAL ASSEMBLY. (C.A.) 1996. Visit by delegation of Constitutional Assembly members and technical advisors to Germany 9-15 January 1996.

CHASKALSON, Matthew, KENTRIDGE, Janet, KLAAREN, Jonathan, MARCUS, Gilbert, SPITZ, Derek \& WOOLMAN, Stuart 1996. Constitutional law of South Africa Kaapstad : Juta

CILLIERS, J 1992. The National Party and federalism. (In Kriek, D J ed. Federalism: The solution? Pretoria : RGN-uitgewers. p. 239-266.)

DE CONING, Christo. 1994 The territorial imperative: Towards an evaluation of the provincial demarcation process. (In De Villiers, Bertus ed. Birth of a constitution. Kaapstad : Juta. p. 189-222.)

DE LILLE, Patricia. 1995. Where do we go from here? More or less federalism? Provincial constitution-making. Pan Africanist Congress. (In Kotzé, Hennie ed. The political economy of federalism in South Africa: Policy opportunities and constraints of the Interim Constitution. Stellenbosch : Universiteit van Stellenbosch/Konrad-AdenauerStiftung. p. 175-178.) 
Federalisme as 'n proses: 'n evaluering van die 1996-grondwet

DE VILLE. Jacques. 1995. Guidelines for judicial review on "division of powers" grounds. Stellenbosse Regstydskrif, 6(2):139-160

DE VILLIERS, Bertus. 1994. The constitutional principles - Content and significance. (In De Villiers, Bertus ed. Birth of a constitution Kaapstad : Juta. p. 37-49.)

DU PLESSIS, Lourens M. \& ERASMUS, H J. 1988. Section 100 of the Magistrates' Court Act in view of the new system of provincial government. The South African Law Journal, 105(4):763-768.

DU PLESSIS, Lourens M 1986. The interpretation of statutes Durban : Butterworths

DU PLESSIS, Lourens \& CORDER, Hugh. 1994. Understanding South Africa's transitional Bill of Rights. Kaapstad : Juta.

ELAZAR, Dan. 1994a. Form of state: Federal, unitary, or ... (In De Villiers, Bertus ed. Birth of a constitution. Kaapstad : Juta. p. 29-36.)

ELAZAR, Daniel J. 1994b. Can American federalism help South Africa? (In Licht, Robert A. \& De Villiers, Bertus eds South Africa's crisis of constitutional democracy. Can the US Constitution help? Washington DC : A.E.I. Press. p. 62-86)

FINANCIAL AND FISCAL COMMISSION. 1995. Framework document for intergovernmental fiscal relations in South Africa. 19 June 1995.

FINANCIAL AND FISCAL COMMISSION. 1996. The Financial and Fiscal Commission's recommendations for the allocation of financial resources to the national and provincial governments for the 1997/98 financial year. May 1996.

FORSYTH, Murray. 1984. Federalism and the future of South Africa. Braamfontein : SA Institute for International Affairs. (Bradlow Series no. 2.)

KARPEN, Ulrich. 1994. Federalism - An important instrument for providing pluralism in the new democratic South Africa. (In Occasional Papers, April 1994 Johannesburg : Konrad-Adenauer-Stiftung. p. 3-7.)

KENYON-HOARE, Alan 1995. Where do we go from here? More or less federalism? Provincial constitution-making. African Christian Democratic Party. (In Kotzé, Hennie ed. The political economy of federalism in South Africa: Policy opportunities and constraints of the Interim Constitution. Stellenbosch : Universiteit van Stellenbosch/ Konrad-Adenauer-Stiftung. p. 179-182.)

KOTZÉ, Hennie. 1995a. Introduction. (In Kotzé, Hennie ed. The political economy of federalism in South Africa: Policy opportunities and constraints of the Interim Constitution. Stellenbosch : Universiteit van Stellenbosch/Konrad-Adenauer-Stiftung. p. 1-6.)

KOTZE, Hennie. 1995b. Federalism in South Africa: An overview. (In Kotzé, Hennie ed The political economy of federalism in South Africa: Policy opportunities and constraints of the Interim Constitution. Stellenbosch : Universiteit van Stellenbosch/ Konrad-Adenauer-Stiftung. p. 55-82.)

KRIEK, Dan \& SONO, Themba 1995. How federal is the Interim Constitution? (In Kotzé, Hennie ed. The political economy of federalism in South Africa: Policy opportunities and constraints of the Interim Constitution. Stellenbosch : Universiteit van Stellenbosch/ Konrad-Adenauer-Stiflung. p. 83-96.)

KRIEK, D.J. 1992a. Historical development of federalism. (In Kriek, D.J. ed. Federalism: The solution? Pretoria : RGN-uitgewers. p. 1-11.)

KRIEK, D J. 1992b. The theory and practice of federalism. (In Kriek, D.J. ed Federalism: The solution? Pretoria : RGN-uitgewers. p 11-34.)

KRIEK, D.J. 1992c. Confederalism. (In Kriek, D J. ed Federalism: The solution? Pretoria : RGN-uitgewers. p. 97-116.) 
Lourens M. du Plessis

KRIEK, D.J. 1992d. Federal proposals before and during the National Convention 19081909. (In Kriek, D.J. ed. Federalism: The solution? Pretoria : RGN-uitgewers. p. 135148.)

KRIEK, D.J. 1992e. The federation plans of the Democratic Party. (In Kriek, D.J. ed. Federalism: The solution? Pretoria : RGN-uitgewers. p. 231-238)

LEON, Tony. 1995. Where do we go from here? More or less federalism? Provincial constitution-making. Democratic Party. (In Kotzé, Hennie ed. The political economy of federalism in South Africa: Policy opportunities and constraints of the Interim Constitution. Stellenbosch : Universiteit van Stellenbosch/Konrad-Adenauer-Stiftung. p. 171-174.)

LEONARDY, Uwe. 1994 South Africa's constitutional provisions on devolution and federalism (In De Villiers, Bertus ed. Birth of a constitution. Kaapstad : Juta. p. 144171.)

MATTES, Rober. 1995. The international experience: Lessons for South Africa? United States of America. (In Kotze, Hennie ed. The political economy of federalism in South Africa: Policy opportunities and constraints of the Interim Constitution. Stellenbosch Universiteit van Stellenbosch/Konrad-Adenauer-Stiftung. p. 39-54.)

MEYER, Roelf. 1995. Where do we go from here? More or less federalism? Provincial constitution-making. African National Congress and the National Party (GNU). (In Kotzé, Hennie ed. The political economy of federalism in South Africa: Policy opportunities and constraints of the Interim Constitution. Stellenbosch : Universiteit van Stellenbosch/Konrad-Adenauer-Stiftung. p. 157-162.)

MOLT, Peter. 1995. The international experience: Lessons for South Africa? Germany. (In Kotzé, Hennie ed. The political economy of federalism in South Africa: Policy opportunities and constraints of the Interim Constitution. Stellenbosch : Universiteit van Stellenbosch/Konrad-Adenauer-Stiftung. p. 35-38.)

MTIMKULU, P.F G. 1992. The Buthelezi Commission's federal proposals. (In Kriek, D.J. ed. Federalism: The solution? Pretoria : RGN-uitgewers. p. 205-212.)

MULDER, Pieter. 1995. Where do we go from here? More or less federalism? Provincial constitution-making. Freedom Front. ( $m$ Kotzé, Hennie ed The political economy of federalism in South Africa: Policy opportunities and constraints of the Interim Constitution. Stellenbosch : Universiteit van Stellenbosch/Konrad-Adenauer-Stiftung. p. 167-170.)

NGUBANE, Ben. 1995. Where do we go from here? More or less federalism? Provincial constitution-making. Inkatha Freedom Party. (In Kotzé, Hennie ed. The political economy of federalism in South Africa: Policy opportunities and constraints of the Interim Constitution. Stellenbosch : Universiteit van Stellenbosch/Konrad-AdenauerStiftung. p. 163-166.)

OLIVIER, Pierre. 1994. Constitutionalism and the new South African Constitution. (In De Villiers, Bertus ed. Birth of a constitution. Kaapstad : Juta. p. 50-74.)

SCHNEIDER, Hans-Peter \& KRAMER, Jutta. 1996. Das Fundament des Regenbogens. Ein Zeugnis der Verständigung - die Verfassung des neuen Südafrika. Mitteilungen des Deutschen Instituts fur Föderalismusforschung e.V. Hannover :17-27, Julie.

SHUBANE, Khehla. 1994. Provincial institutions. (In De Villiers, Bertus ed. Birth of a constitution. Kaapstad : Juta p. 230-241.)

WATTS, Ron. 1994a. Is the new South African Constitution federal or unitary? (In De Villiers, Bertus ed. Birth of a constitution. Kaapstad : Juta. p 75-88.)

WATTS, Ron. 1994b. Provincial Representation in the Senate. ( $m$ De Villiers, Bertus ed Birth of a constitution. Kaapstad : Juta. p. 125-143.) 
Federalisme as 'n proses: 'n evaluering van die 1996-grondwet

WATTS, Ron. 1994c. Contemporary views on federalism. ( $\mathrm{l}$ De Villiers, Bertus ed. Evaluating federal systems. Kaapstad : Juta, Dordrecht/Boston/Londen : Nijhoff. p. 129.)

WELSH, David. 1994. The provincial boundary demarcation process. (In De Villiers, Bertus ed. Birth of a constitution. Kaapstad : Juta. p. 223-229.) 